\title{
Towards effective reforestation: growth and commercial value of four commonly planted tropical timber species on infertile soils in Panama
}

\author{
Katherine Sinacore ${ }^{1}$ (D ) Edwin H. García ${ }^{1,2} \cdot$ Theodore Howard $^{3}$. \\ Michiel van Breugel ${ }^{1,4}$ (D) Omar R. Lopez ${ }^{1,5}$ (D) Alex J. Finkral ${ }^{6} \cdot$ Jefferson S. Hall $^{1}$ (D)
}

Received: 3 September 2020 / Accepted: 6 February 2022 / Published online: 25 February 2022

(C) The Author(s) 2022

\begin{abstract}
Finding suitable tree species that not only grow well on nutrient poor soils but are also safe financial investments is one of the major obstacles to successful reforestation efforts in the tropics. Our study compared the financial viability and growth of valuable timber species in monocultures and mixtures on infertile soils. Our work shows the extraordinary growth in volume and value of Dalbergia retusa and Terminalia amazonia while underscoring the poor financial viability of Tectona grandis and Pachira quinata, all commonly planted timber species in Panama and much of Central and South America. Using Bayesian statistics, our predictions show that $T$. amazonia monocultures could reach nearly $200 \mathrm{~m}^{3} \mathrm{ha}^{-1}$ of merchantable volume after 30 years compared to the $\sim 40 \mathrm{~m}^{3} \mathrm{ha}^{-1}$ that $T$. grandis could accumulate in the same time frame. While $D$. retusa monocultures did not have the highest predicted merchantable volumes of all the species, it did have the highest predicted net present value (NPV), with a predicted mean NPV of $>$ US $\$ 97,000 \mathrm{ha}^{-1}$, quadrupling the species with the next highest monoculture's NPV, T. amazonia monocultures $\left(\sim\right.$ US $\left.\$ 20,000 \mathrm{ha}^{-1}\right)$. Our work emphasizes that reforestation can be financially viable on low nutrient soils, even in the absence of fertilization or other silvicultural manipulations, if species selection and site are carefully considered and matched.
\end{abstract}

Keywords Agua Salud Project $\cdot$ Dalbergia retusa $\cdot$ Net present value $\cdot$ Terminalia amazonia . Timber value $\cdot$ Tree volume

Katherine Sinacore

ksinacore@gmail.com

1 ForestGEO, Agua Salud Project, Smithsonian Tropical Research Institute, Balboa, Ancón, Panamá, Panama

2 Facultad de Ciencias Naturales, Exactas y Tecnología, Universidad de Panamá, Ciencias Biológicas, Panama City, Panama

3 University of New Hampshire, Durham, NH, USA

4 Yale-UNS College, College Avenue West, Singapore, Singapore

5 Instituto de Investigaciones Científicas y Servicios de Alta Tecnología (INDICASAT), Edifico 209, Clayton, Panama

6 The Forestland Group, LLC, Chapel Hill, NC, USA 


\section{Introduction}

There is widespread recognition that tree planting is one of the most sustainable methods for offsetting carbon emissions to reach targets set by international climate agreements (Griscom et al. 2017; Bastin et al. 2019a; Lewis et al. 2019). As recently as 2019, many initiatives, like the Trillion Tree Campaign, the Bonn Challenge, and Fortune 500 companies at the World Economic Forum, have touted tree planting as a relatively easy and efficient way of offsetting trillions of tonnes of carbon dioxide that is emitted annually. From a global perspective, studies like Bastin et al. (2019a) have used advanced machine learning to further simplify the planning process for tree planting by modeling where in the world trees can be planted. However, as the authors note in a response to criticism (Bastin et al. 2019 b), just because there is available land to plant trees, does not imply that trees can or should be planted in those areas (Holl and Brancalion 2020). Foresters have long recognized the importance of matching species to site (Smith et al. 1997) and silvicultural principles emphasize that tree planting must be carefully planned to ensure proper species are planted in the correct areas for the right reasons and at the right time (Hall et al. 2011; van Breugel et al. 2011; Hall and Ashton 2016). At local scales, small differences in soil nutrients and soil $\mathrm{pH}$ can lead to large differences in yield, depending on the species identity (Mayoral et al. 2019), further complicating reforestation efforts; species selected for reforestation in the tropics also need to withstand the harsh conditions of growing in full sun.

While studies of shade tolerance in nurseries form the bedrock for reforestation research today (e.g. Augspurger and Augspurger 1984; Ashton 1995; Singhakumara et al. 2003), how species perform in nurseries can be very different from how they will perform onsite due to differences in light requirements, soil nutrients, pets and pathogens, and rainfall regimes that are not as uniform across a landscape as they are in a nursery. In the past few decades, researchers have performed studies that help fill that knowledge gap by studying the survival and growth of saplings and trees across precipitation and soil nutrient gradients in situ (e.g. Butterfield 1995; van Breugel et al. 2011; Martin-Benito et al. 2018). With a better foundation of how certain species perform on site, reforestation research has expanded to include species trials which have focused on testing how species interactions might affect tree growth and survival (e.g. Kelty 1992; Potvin et al. 2011; Ewel et al. 2015; Hutchison et al. 2018).

An important but often elusive component of reforestation is estimating the value of the plantations at harvest. Valuing plantations is not new and has been well researched in the tropics, especially for species of high economic value (e.g. Howard and Valerio 1996 and Piotto et al. 2010 from Costa Rica; Rode et al. 2014 and Medeiros et al. 2020 from Brazil, and Stille et al. 2011, Pandey et al. 2016 and Bhangu 2018 from India, and Griess and Knoke 2011 from Panama). Most of these studies focus on species with a developed international market (e.g., Tectona grandis, or teak) and grown on relatively nutrient rich soils (but not Piotto et al. 2010) that are ideal for plantation management. However, most of the available land in Panama for planting is positioned on low $\mathrm{pH}$ and low nutrient soils (Zonificación de Agropecuaria de Panamá 2006), where trees may have difficulty surviving and growing. Economic value of trees is linked to both the growth and survivability of the planted trees, but not all tree species that are productive and have low mortality are equally valuable in timber markets. The reverse is also true, not all high value species will grow well on all lands or survive and have good form (Didier et al. 2016; dos Reis et al. 2019).

Panama offers a unique setting to study the growth and financial value of a few commonly planted species. The body of knowledge surrounding growth of native tree 
species in Panama has been steadily expanding in the last few decades (e.g. Wishnie et al. 2007; Healy et al. 2008; Hall et al. 2011; Hall and Ashton 2016; Mayoral et al. 2019; Schnabel et al. 2019) and already exists for an introduced species, T. grandis. While $T$. grandis may have the advantage over native species in that it is highly profitable in areas of Malaysia, where it is native (Kollert and Chrubini 2012), and has proven to perform well in Panama (Sloan 2007; Kirby and Potvin 2017), successful growth of T. grandis in Panama is confined to relatively nutrient rich soils in the eastern part of Panama in the Province of the Darién (Zonificación de Agropecuaria de Panamá 2006). Yet in areas of low soil fertility which comprise the majority of the land available for planting in Panama (Zonificación de Agropecuaria de Panamá 2006), T. grandis grows poorly. Despite this, T. grandis was widely planted in Panama since the 1990s due to government incentive structures (Hall et al. 2015) and occurred before government planners understood how poorly $T$. grandis performed on certain soils and before information about other species was widely available. Today, nearly $70 \%$ of planted trees in Panama are T. grandis, with the $30 \%$ remaining including pine (introduced), eucalyptus (introduced), and a few native species (FAO 2015). Yet the poor performance of $T$. grandis in much of Panama provides an opening for native species that are well adapted to nutrient poor soils.

Work globally and in Panama underlines the potential growth and survivability of native species (Montagnini et al. 1995; Ashton et al. 2001; Griscom et al. 2005; Plath et al. 2011; Forrester and Smith 2012; Schnabel et al. 2019), but T. grandis has the advantage that the market and financial knowledge is documented and available online from the International Tropical Timber Organization (ITTO) and through the Center for International Forestry Research (CIFOR) or the Food and Agriculture Organization (FAO). To transition away from planting $T$. grandis and toward planting other species, at the most basic level, alternative species must be at least as profitable as $T$. grandis (on a given site) and have an existing market, if the objective is purely financial. Although there are clear challenges, Panama has already experienced a small shift away from cattle ranching and towards forests naturally regenerating in some areas where cattle ranching dominated for decades (Hall et al. 2022; Wright and Samaniego 2008; Tarbox et al. 2018). That transition could be a harbinger for shifts in species selected for reforestation.

While some studies publish the economics of plantation forestry (e.g., Piotto et al. 2010; Griess and Knoke 2011; Paul et al. 2015), including final yields and prices, much of the current information that exists on growth and yield for native species or species new to commercial markets is proprietary and thus not available for practitioners and landowners. The objective of this study was to compare three native species and $T$. grandis's volume yield and net present value on nutrient poor soils in Central Panama, a region characterized by moist tropical forests. The three alternative (native) species we focus on here include Terminalia amazonia (amarillo), Dalbergia retusa (cocobolo), and Pachira quinata (cedro espino), which are timber and craft wood species that are relatively well known throughout Panama and Central America. We seek to address the question: are these species (in monocultures and mixtures) financially profitable to plant on nutrient poor soils in Panama?

We use eight to ten years of inventory data for the four species and model the predicted growth into the future. Combined with market data for the three alternatives and T. grandis, we estimate the net present value for monocultures and mixtures of these species to determine if a business case can be made for planting any of these species or combinations of them. 


\section{Methods}

\section{Site description}

This study was conducted at the Agua Salud Project site located in the Panama Canal Watershed $\left(9^{\circ} 13 \mathrm{~N}^{\prime}, 79^{\circ} 47^{\prime} \mathrm{W}, 33 \mathrm{~m}\right.$ amsl) with an average rainfall of $2700 \mathrm{~mm}$ annually, $80 \%$ of which falls between May and mid-December. Mean daily maximum and minimum temperatures are $32{ }^{\circ} \mathrm{C}$ and $23{ }^{\circ} \mathrm{C}$ (Stallard et al. 2010; Ogden et al. 2013). The topography is characterized by short and steep slopes (Hassler et al. 2011; Mayoral et al. 2017). Soils are silt clay to clay with $\mathrm{pH}$ values of 4.4 to 5.8 and have very low levels of both plant available and total phosphorus (Mayoral et al. 2019; van Breugel et al. 2019). The data were collected from the Agua Salud native species and T. grandis plantation, both established in 2008 and planted in the same $3 \mathrm{~m}$ by $3 \mathrm{~m}$ spacing configuration. The native species plantations are located in two blocks, $3 \mathrm{~km}$ apart, while the $T$. grandis plantation is located in one 30 ha block crossing two distinct drainages. In each block of the native species plantation, 20 different treatments composed of monocultures and mixtures, are spread across the 37.5-ha area ( 2 blocks $\times 37.5$ ha $=75$ ha total). The measured areas of the native species plots are $27 \mathrm{~m}$ by $23.4 \mathrm{~m}$ as three rows of trees on each side were not measured to avoid edge effects. Plots in the T. grandis monoculture were $25 \mathrm{~m}$ by $25 \mathrm{~m}$. A total of 1,283 trees were planted per hectare in both the native species and T. grandis plantations. In the mixtures, the plantation was designed so that species A was completely surrounded by species B in a hexagonal configuration. For each plot there are 9 hexagons (with trees planted in between to fill in rows), with 5 of the hexagons being species A surrounded by species B and the other 4 having the verse pattern for configuration 1 . Half of the mixed species plots follow the first configuration and half follow the second (for more details: Mayoral et al. 2017 and van Breugel and Hall 2008). We focused on 7 treatments divided into monocultures and mixtures. Monocultures included D. retusa (Dr mono), $P$. quinata (Pq mono), T. amazonia (Ta mono), and T. grandis (Tg mono). We also included treatments of two species mixtures for D. retusa, P. quinata, and T. amazonia (Dr-Pq mix, Dr-Ta mix, and Pq-Ta mix). The other species in the native species plantation were not included in this study because they performed poorly across the landscape and/or had low market availability (Mayoral et al. 2017). Annual inventories of the native species plantation (from 2008 to 2018, except 2017) measured the basal diameter (BD) and diameter at breast height $(\mathrm{DBH})$ of each tree within the core area of each plot ( 81 trees per plot). Each treatment has between 11 and 13 plots, so that a total of 5719 trees were measured per year for the native species. Total height $(\mathrm{H})$ of each tree was measured with expandable poles until 2015, after which many trees were beyond the 15 -m pole length and too tall to accurately measure such that height measures were thus excluded from annual inventories after 2015. Inventories of the T. grandis plantation have been completed twice, once in 2013 (Hall 2013) and once in 2016, with a total of 48 plots, so that a total of 3,888 trees were measured for each inventory (Marshall et al. 2020).

\section{Taper and volume estimates}

Tectona grandis taper and volume equations are well documented in the literature. We selected a Panama-specific T. grandis equation to estimate the volume per tree on our plantation using DBH (Kraenzel et al. 2003). For D. retusa, P. quinata, and T. amazonia, 
volume and taper equations are not well documented, so we harvested trees in the Agua Salud plantation to estimate volume (García et al. unpublished). A total of 88 trees were harvested (D. retusa: 33, P. quinata: 28 , and T. amazonia: 27$)$ in monocultures and twospecies mixtures, all 11 years of age at the time of harvest. Data from previous inventories on the plantations were used to find the minimum and maximum diameters at breast height (DBH) for each species in each treatment (for T. amazonia, 3.45-27.50 cm DBH; for $D$. retusa $1.70-28.30 \mathrm{~cm} \mathrm{DBH}$; for $P$. quinata $0.75-35.70 \mathrm{~cm} \mathrm{DBH).} \mathrm{Those} \mathrm{ranges} \mathrm{were} \mathrm{split}$ into $2 \mathrm{~cm}$ bins and trees were randomly selected until each bin was filled. For each tree, the $\mathrm{BD}, \mathrm{DBH}$, and $\mathrm{H}$ were measured. Height was measured using a $15-\mathrm{m}$ pole if the tree was less than $15 \mathrm{~m}$ tall, otherwise trees were measured with a measuring tape once felled. Diameters on the main bole of the tree were measured at regular intervals along the length of the tree. Merchantable height was measured up to a $10 \mathrm{~cm}$ diameter (Fig. S1). We used the Smalian formula (Avery and Burkhart 2015) to estimate volume of each segment for each tree:

$$
V=\left[\frac{B+b}{2}\right] \times L
$$

where $V\left(\mathrm{~m}^{3}\right)$ is the estimated volume over bark, $B\left(\mathrm{~cm}^{2}\right)$ is the cross-sectional area at the large end of the $\log , b\left(\mathrm{~cm}^{2}\right)$ is the cross-sectional area of the small end of the log, and $L(\mathrm{~m})$ is the length of the $\log$. The segments for each tree were then summed to calculate the volume of the bole of the tree. To estimate volume from BD, we used the volumes calculated from the Smalian formula to create ten different models $(M)$ that are commonly used to estimate volume of a tree using some combination of $\mathrm{DBH}, \mathrm{H}$, or $\mathrm{BD}$. We tested the models using $\mathrm{DBH}$ and $\mathrm{BD}$ and found no differences in the models' predictive ability (see below). As such, we used BD because BD measurements are available on the plantation from the beginning of the plantation inventory, while many trees did not reach breast height until a few years into the study. We also excluded models that included height because height measurements ceased after 2015, which removed three models from consideration. Although we used the length of harvested trees to estimate volume, those data only represent a subset of all the trees inventoried on the plantation for which we have good measurements of height. Initially, we separated the models based on treatments (monocultures vs. mixtures), but the models were weaker with fewer data points, so we aggregated by species:

$$
\begin{aligned}
M 1: v & =a+b \times b d \\
M 2: v & =a+b \times(b d)^{2} \\
M 3: \log (v) & =a+b \times \log (b d) \\
M 4: \operatorname{sqrt}(v) & =a+b \times b d \times c \times b d^{2} \\
M 5: v & =a+b \times b d \times c \times b d^{2} \\
M 6: v & =a+b \times b d \times c \times b d^{2}+d \times b d^{3} \\
M 7: v & =a+b \times b d^{2} \times c \times b d^{3}
\end{aligned}
$$

where $v$ is volume $\left(\mathrm{m}^{3}\right), b d(\mathrm{~cm})$ is basal diameter and $a, b, c$ and $d$ are model constants. The best model for $T$. amazonia and D. retusa was $M 7$ and $M 6$ for $P$. quinata, selected based on AICc $\Delta$ and goodness of fit (Table 1; Fig. S2). AICc $\Delta$ was used over AIC because it includes a correction to prevent overfitting and is recommended for small datasets. We used $M 7$ or $M 6$ and the species-specific coefficients to determine tree volume for the three 
Table 1 Goodness of fit for selected models and AICc $\Delta$ for seven volume models

\begin{tabular}{|c|c|c|c|c|c|c|}
\hline Species & Model & $\mathrm{a}$ & $\mathrm{b}$ & $\mathrm{c}$ & $\mathrm{d}$ & $\mathrm{R}^{2}$ \\
\hline T. amazonia & $\mathrm{m} 7$ & -0.03 & 0.0008331 & 0.00001902 & & 0.83 \\
\hline D. retusa & $\mathrm{m} 7$ & 0.006779 & 0.000009488 & 0.000007838 & & 0.88 \\
\hline P. quinata & $\mathrm{m} 6$ & 0.06057 & -0.0364 & 0.001026 & -0.00001576 & 0.96 \\
\hline $\operatorname{AICc} \Delta$ & T. amazonia & D. retusa & P. quinata & & & \\
\hline $\mathrm{m} 1$ & 0.07 & 28.87 & 7.60 & & & \\
\hline $\mathrm{m} 2$ & 1.61 & 10.77 & 5.88 & & & \\
\hline $\mathrm{m} 3$ & 3.15 & 11.07 & 5.62 & & & \\
\hline $\mathrm{m} 4$ & 8.25 & 2.82 & 2.32 & & & \\
\hline m5 & 1.61 & 8.54 & 5.62 & & & \\
\hline m6 & 3.15 & 11.07 & 0.00 & & & \\
\hline $\mathrm{m} 7$ & 0.00 & 0.00 & 2.74 & & & \\
\hline
\end{tabular}

Models created independently for D. retusa, $P$. quinata, and T. amazonia. Top panel shows the selected model for each species, the constants, and the adjusted $\mathrm{R}^{2}$. The bottom panel shows the AICc $\Delta$ for each species and model

alternative species from 2008 through 2018 (see Fig. S3 for tree-level volume estimates). We applied tree volume equations to inventory data to calculate the volume per hectare for each plot. The volumes presented are merchantable volumes, not total tree volumes, as they exclude branches, roots and sections too small for markets.

\section{Future tree and stand volume estimates}

We used Bayesian statistics in the stan package (Stan Development Team 2020) in R ( R Core Team 2017) to estimate the stand volume by species and treatment until age 30 for all 4 species and all 7 treatments. A rotation age of 30 was chosen because it is close to the rotation age for D. retusa provided by our contacts in the forestry industry in Panama. It is possible, with $T$. amazonia's growth rates that the rotation age could be less than 30 years. T. grandis is typically managed on a 20 to 25-year rotation in Panama on nutrient rich soils (Stefanski et al. 2015) whereas on nutrient rich sites, $P$. quinata likely needs longer than 30 years to reach harvest age (Navarro and Martinez 1988). Nevertheless, all species will have reached an asymptote for volume before age 30 based on our predictions (see below). As the plantation in Agua Salud was not designed as a timber plantation, nor has it reached rotation age, we were unable to use exact financial optimal rotation ages for this study. The model used age (first 10 years of growth for natives and 2 years at ages 5 and 8 for $T$. grandis) to predict volume per tree and volume per hectare of each species and treatment. Each model run for species and treatment included 100 chains and 2000 iterations. The stan output includes credible intervals of $95 \%$ and $90 \%$ around the predicted stand volumes for each species and treatment. Bayesian statistics allows the comparison of best case and worse case scenarios using the credible intervals, in terms of volume, which can then be used in the calculation of net present value. The modeled probability levels, combined with the Bayesian visualizations, allow easier interpretation of worst and best case scenarios (Salles et al. 2019). Timber volumes were calculated in cubic meters. For T. grandis, volumes were adjusted using the Hoppus rule - the standard of measure with 
which T. grandis is bought worldwide-which is $78.5 \%$ of the cubic volume (Freese 1973). There are no data available for how to determine the true cubic volume for T. amazonia nor $P$. quinata but as our price data was based on standing volume, we do not consider this to be of great concern. For D. retusa, nearly the entire tree is sold, down to small diameters, including roots because pieces are used in artistry; regardless, our volume estimates do not include small branches or roots because the equations are based on the volume of the bole (or boles) of the tree. All references to cubic meters throughout the paper will refer to the conversion for the $T$. grandis (hoppus rule) and cubic meters for the native species.

\section{Net present value}

To determine financial viability, we calculated net present value (NPV) which is the time series of future cash flows discounted by an interest rate to a common point in time (the present) to reflect the value of money. NPV of each treatment was calculated using the mean, minimum, and maximum volume outputs per hectare at age 30 that were predicted from the selected models. The minimum and maximum values are based on the credible interval outputs from the Bayesian analysis. We selected species specific prices per cubic meter based on other studies, personal communication with landowners, and one of the authors (Finkral) (Piotto et al. 2010; Griess and Knoke 2011; Paul et al. 2015). We included a mid-range price, a lower limit, and an upper limit for each species (Table 2) and varied the nominal interest rate from 1 to $15 \%$ in the NPV equation:

$$
N P V=-C_{0}+\left[\left(R_{t}-C_{t}\right) \div(1+r)^{t}\right]
$$

where $-C_{o}$ is the initial costs (US\$), $R_{t}$ is the revenue (US\$), $C_{t}$ is the cost (US\$), and $r$ is the interest rate. The interest rate, or the cost of borrowing money, for reforestation in Panama is generally between 5 and 13\% (Griess and Knoke 2011; Stefanski et al. 2015). We can also identify the internal rate of return by solving for $r$ when the NPV is equal to zero. We created three different scenarios, changing the establishment costs and maintenance costs in each scenario, but maintaining the cost of harvesting for each scenario at US\$65 per $\mathrm{m}^{3}$, a value used by one of us (Finkral) for estimating harvest costs on plantations in Panama. Scenario 1 assumed establishment costs for T. grandis and the native species to be US\$960 per hectare (ha) and US\$1200 ha ${ }^{-1}$, respectively. The maintenance costs (e.g. cleaning below planted trees) for years 1 through 4 decreased overtime (US\$640 ha ${ }^{-1}$, US\$580 ha ${ }^{-1}$, US $\$ 500 \mathrm{ha}^{-1}$, and US $\$ 480 \mathrm{ha}^{-1}$ ). Scenario 2 assumed establishment costs for $T$. grandis and the native species to be US\$1200 and US\$1500 ha ${ }^{-1}$, respectively, with decreasing maintenance costs from year 1 to year 4 (US\$800, US\$725, US\$625, US $\$ 600 \mathrm{ha}^{-1}$ ). Finally, Scenario 3 assumed establishment costs for $T$. grandis and the native species to be US\$1440 and US\$1800 ha ${ }^{-1}$, respectively, with decreasing

Table 2 Upper, lower, and middle prices (US\$ per cubic meter) for study species

\begin{tabular}{lllll}
\hline & D. retusa & P. quinata & T. amazonia & T. grandis \\
\hline Upper & 4000 & 300 & 600 & 600 \\
Middle & 2500 & 200 & 300 & 400 \\
Lower & 500 & 100 & 100 & 200 \\
\hline
\end{tabular}

Prices based on personal communication, data from International Timber Reports, Stefanski et al. (2015) and one of the authors (Finkral) 
maintenance costs from year 1 to year 4 (US\$960, US\$870, US\$750, US\$720 ha ${ }^{-1}$ ). Importantly, the establishment costs for the native species were higher than the T. grandis due to higher costs of nursery material for the native species in Panama. Scenario 2 (the 'average' scenario) is presented in the main body of the manuscript while Scenarios 1 and 3 are presented in the Supplementary Information (Figs. S4 and S5; Tables S1 and S2).

The magnitude of our data (5719 trees measured annually in the native species plantation at 9 time periods and 3888 in the $T$. grandis plantation at two time periods) permitted us to get robust estimates for both volume yield and NPV, with credible intervals that include both variation in volume yields and log prices.

\section{Results}

\section{Tree diameters and stand volume}

Basal diameter for the three native species varied over time, but after 10 years of growth, both $T$. amazonia and $P$. quinata had similar ranges of basal diameters (BD), $14.4 \pm 5.70 \mathrm{~cm}$ and $12.26 \pm 5.99 \mathrm{~cm}$, respectively (Table 3 ) while D. retusa was the species with the smallest BD $(9.67 \pm 5.15 \mathrm{~cm})$.

For the first three years of the plantations, the stand volume for the six native treatments (Ta mono, Dr mono, Pq mono, Dr-Pq mix, Dr-Ta mix, Pq-Ta mix) were not significantly different (95\% confidence intervals overlapping with the means, Fig. 1). By age 10, T. amazonia monocultures had the highest stand volume, averaging $90 \mathrm{~m}^{3} \mathrm{ha}^{-1}$. The next highest stand volumes at age 10 included $P$. quinata-T. amazonia mixtures $\left(75 \mathrm{~m}^{3} \mathrm{ha}^{-1}\right)$ and D. retusa-T. amazonia mixtures $\left(74 \mathrm{~m}^{3} \mathrm{ha}^{-1}\right)$. Monocultures of D. retusa, P. quinata, and T. grandis had substantially lower stand volume over time, all less than $60 \mathrm{~m}^{3} \mathrm{ha}^{-1}$ (Fig. 1). T. grandis performed especially poorly, only obtaining a volume of between 16 and $17 \mathrm{~m}^{3} \mathrm{ha}^{-1}$ at 8 years. We note that the data for the two measurement periods fall on the same site index curves (site IV—-poor) published by Keogh (1982).

\section{Predicted stand volume}

The treatment with the highest predicted volume at age 30 was monocultures of T. amazonia, with a predicted volume of nearly $200 \mathrm{~m}^{3} \mathrm{ha}^{-1}$ (Fig. 2a). Monocultures of D. retusa, P. quinata, and T. grandis were predicted to reach $60 \mathrm{~m}^{3} \mathrm{ha}^{-1}, 50 \mathrm{~m}^{3} \mathrm{ha}^{-1}$, and $40 \mathrm{~m}^{3} \mathrm{ha}^{-1}$ respectively by age 30 (Fig. 2d,f,j). The models also predicted that in mixed stands, $T$.

Table 3 Inventory statistics for the three native species at 10 years

\begin{tabular}{llll}
\hline & D. retusa $(\mathrm{n}=2322)$ & P. quinata $(\mathrm{n}=1418)$ & T. amazonia $(\mathrm{n}=1979)$ \\
\hline Basal diameter $(\mathrm{cm})$ & & & \\
Mean $(\mathrm{sd})$ & $9.67 \pm 5.15$ & $12.26 \pm 5.99$ & $14.4 \pm 5.70$ \\
Min & 0.35 & 1.10 & 0.80 \\
Max & 28.0 & 32.0 & 33.3 \\
\hline
\end{tabular}

The mean basal diameter $(\mathrm{cm})$ for $D$. retusa, $P$. quinata, and $T$. amazonia represents the mean and standard deviation (sd) at 10 years of age. The minimum and maximum diameters for each species are shown 


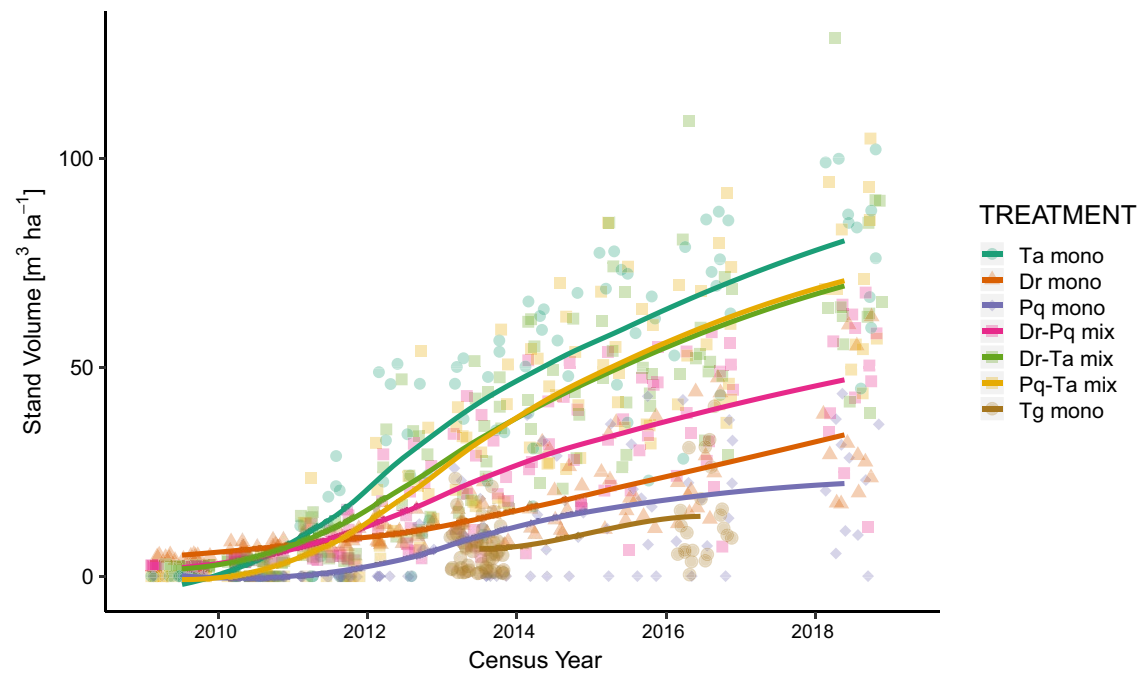

Fig. 1 Actual stand volume by year for each of the treatments. Monocultures (mono) of Ta (Terminalia amazonia), Dr (Dalbergia retusa), Pq (Pachira quinata), and Tg (Tectona grandis) are shown in teal, yellow, green, and brown respectively. Mixtures (mix) of Dr-Pq mix (D. retusa and P. quinata), Dr-Ta mix (D. retusa and T. amazonia), and Pq-Ta (P. quinata and T. amazonia) are shown in pink, orange, and purple, respectively. Points represent individual plots of each treatment and lines represent the mean stand volume $\left(\mathrm{m}^{3} \mathrm{ha}^{-1}\right)$ over time. (Color figure online)

amazonia would obtain a greater volume (about $80 \mathrm{~m}^{3} \mathrm{ha}^{-1}$ ) than the species it is planted with (less than $10 \mathrm{~m}^{3} \mathrm{ha}^{-1}$ ) (Fig. 2b,c,e,h).

\subsection{Predicted net present value}

The highest predicted NPV was that of D. retusa in monocultures (Fig. 3a), with an absolute maximum NPV of US\$210,000 ha $\mathrm{ha}^{-1}$ at an interest rate (IR) of $1 \%$ and $\sim \mathrm{US} \$ 20,000 \mathrm{ha}^{-1}$ at an IR of $6 \%$ for average growth and price (Table 4). The next highest predicted NPV was in mixtures of $D$. retusa and $P$. quinata, followed by monocultures of $T$. amazonia, and mixtures of $D$. retusa and $T$. amazonia. Both $T$. grandis and $P$. quinata monocultures had the lowest NPV, never exceeding US\$12,000 and 7000 ha $^{-1}$, respectively (Fig. 3d,g). However, $P$. quinata never had a positive average mean NPV in Scenario 2, even when the interest rate was 1\%, (Table 4). Alternatively, in the most expensive scenario (Scenario 3), D. retusa monocultures returned a mean NPV that was positive until interest rates reached $>13 \%$ (Table S3).

\section{Discussion}

An important aspect of designing and promoting reforestation in areas with nutrient poor soils is not only selecting species that will survive and grow well, but those that will also meet landowner objectives, including financial returns on the investment of planting. Based on earlier studies at our research site, the trees studied here had low mortality (P. quinata with $5.9 \pm 6.6 \%$, T. amazonia $1.6 \pm 2.8 \%$ and D. retusa $1.2 \pm 1.1 \%$ (Mayoral et al. (2017)) 

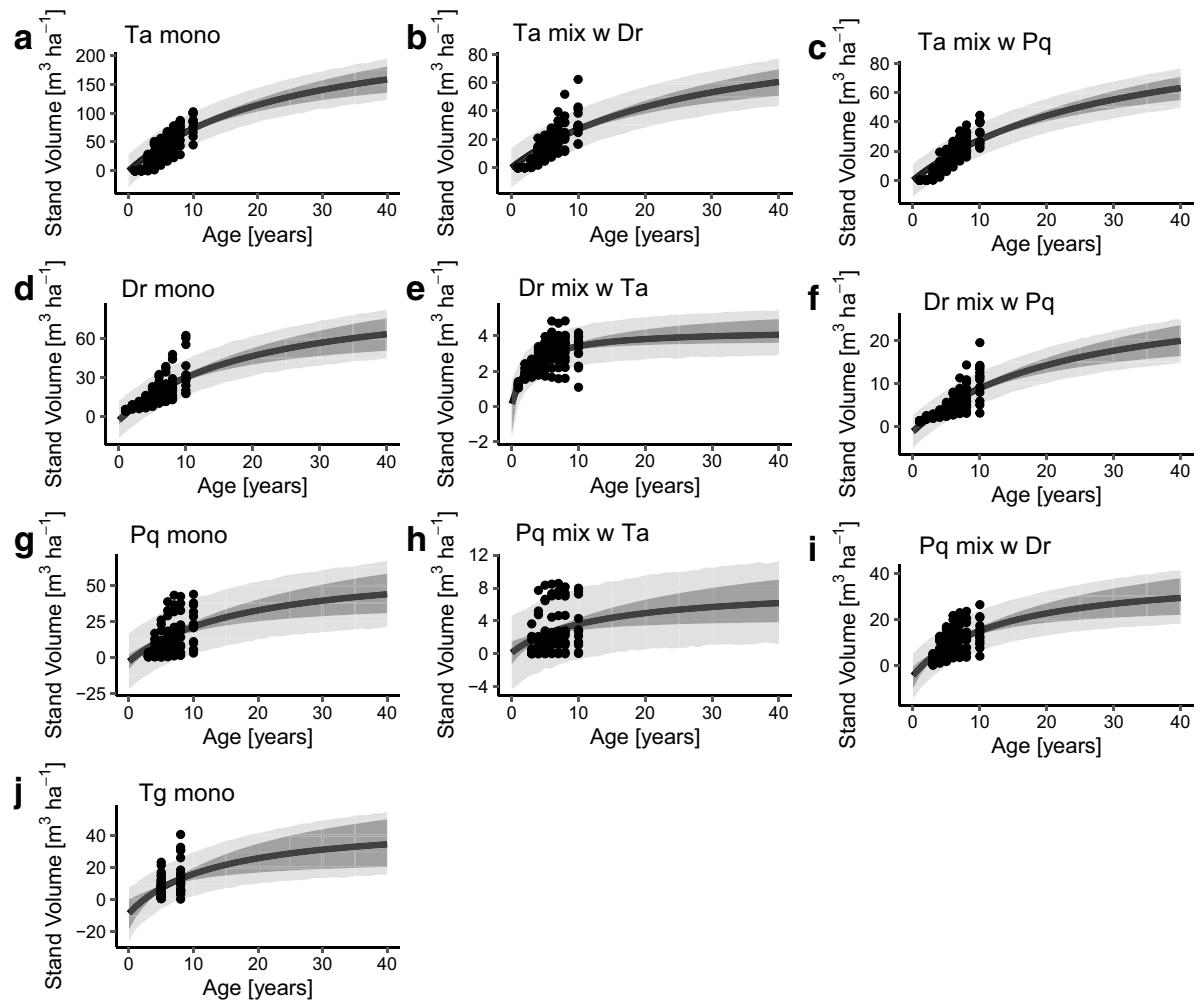

Fig. 2 Actual and predicted stand volume $\left(\mathrm{m}^{3} \mathrm{ha}^{-1}\right)$ over time (years) for four species in monocultures and mixtures. a, d, g, j Monoculture predictions for Ta mono (Terminalia amazonia), Dr mono (Dalbergia retusa), Pq mono (Pachira quinata) and Tg mono (Tectona grandis). b, c, e, f, h, i Two species predictions when one species is planted with a second species showing just the contribution of the volume of the individual species. Black dots represent actual stand level data points. Black line is the predicted stand volume over time. Light gray shading represents credible interval of $90 \%$ and dark gray shading represents credible interval of $95 \%$

in the first 7 years, and thus are good prospects for surviving to rotation age (also see Hall and Ashton 2016 for mortality across a rainfall-soil fertility matrix in Panama). Our study assessed and compared the growth and financial viability of valuable native timber species in monocultures and mixtures on nutrient poor soils with that of the most commonly planted commercial species in Central America, T. grandis. Our work shows the rapid growth in volume and value of $D$. retusa and $T$. amazonia while also underscoring the poor financial viability of $P$. quinata, a commonly planted timber species, on low fertility soils. In addition, our work supported findings of Stefanski et al. (2015) in showing that investing in T. grandis plantations in sites with biophysical conditions similar to ours is a losing prospect in all but the most favorable financial climates (i.e., low interest rates) (Fig. 3g) or when establishment costs are at the low end (Table S1 and Fig. S4g).

Even though $T$. grandis has been shown to grow well outside of Panama (Upadhyay et al. 2005) and parts of Panama where soil fertility is high (Kraenzel et al. 2003; Bermejo et al. 2004), our work shows that T. grandis underperforms in low fertility sites on clay soils (also see Lugo 1997), which are representative of much of Central Panama. 


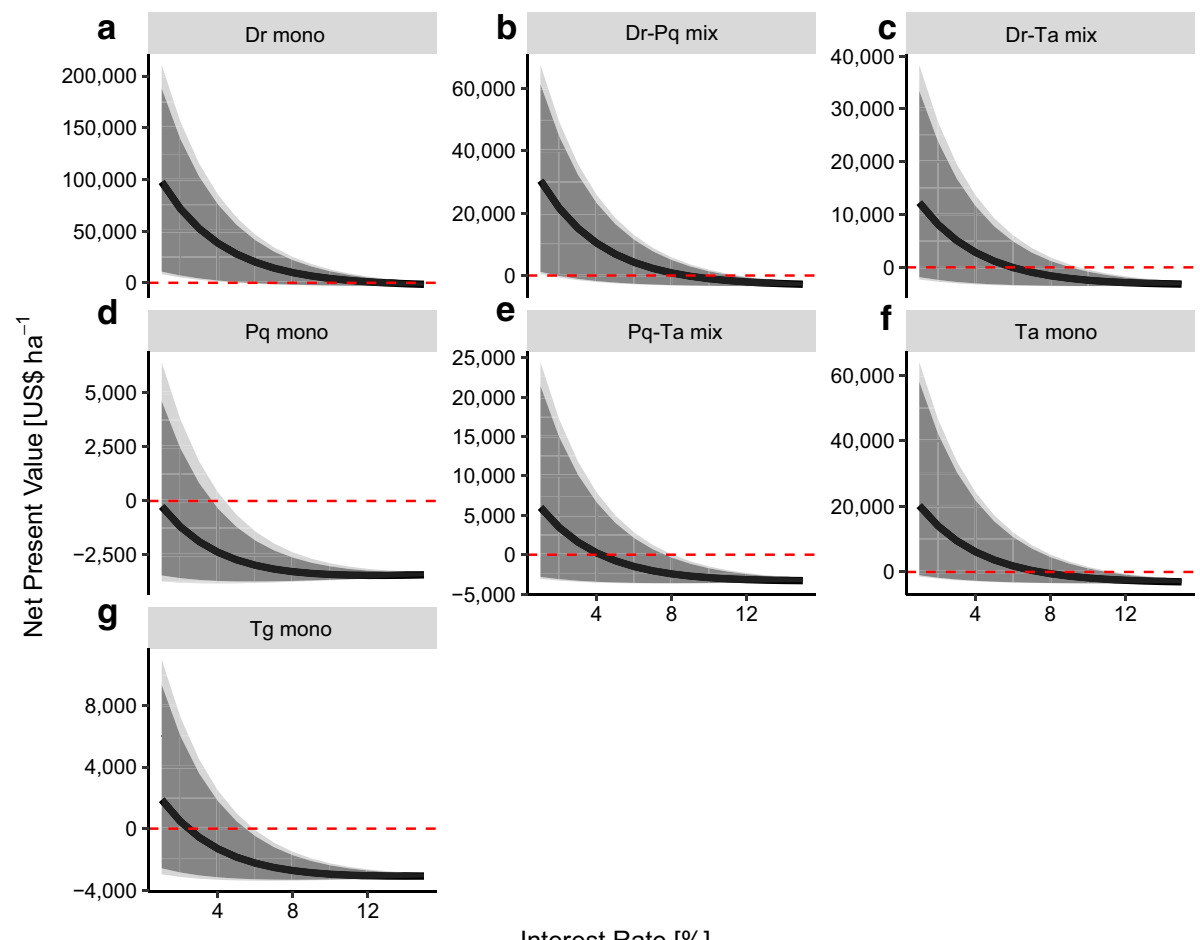

Fig. 3 Modeled net present value (US\$ ha ${ }^{-1}$ ) by interest rate (\%) and treatment for Scenario 2. a, d, f, $\mathbf{g}$ Monoculture predictions for Dr mono (Dalbergia retusa), Pq mono (Pachira quinata), Ta mono (Terminalia amazonia), and Tg mono (Tectona grandis). b, c, e Two species mixtures predictions for Dr-Pq mix ( $D$. retusa and P. quinata), Dr-Ta mix (D. retusa and T. amazonia), and Pq-Ta mix (P. quinata and T. amazonia). Black line is the predicted net present value (NPV) by the interest rate. Light gray shading represents credible interval of $90 \%$ and dark gray shading represents credible interval of $95 \%$. Dashed red line represents where $\mathrm{NPV}=0$. (Color figure online)

When compared to site index curves, the T. grandis in this study fits into Class IV (of five classes) based on work from Puerto Rico, Venezuela, and Colombia (Keogh 1982; Friday 1987; Torres et al. 2012). By tree and stand volume estimates, T. grandis in this study also underperforms compared to $T$. grandis from another study conducted in the Panama Canal Watershed (Stefanski et al. 2015). While the most optimistic models in Stefanski et al. (2015) showed $T$. grandis reaching $>80 \mathrm{~m}^{3} \mathrm{ha}^{-1}$ at age 30 , our most optimistic model showed $T$. grandis reaching just greater than $50 \mathrm{~m}^{3} \mathrm{ha}^{-1}$ at age 30 (Fig. 2j). It should be noted, however, that more than half of the landowners who originally planted $T$. grandis in the Stafanski et al. (2015) study abandoned their plantations due to poor growth by the second measurement and thus were not used to calculate volume and yield. As neither the native species plantation nor $T$. grandis plantation were designed to be managed as a working timber plantation, the sites were not thinned at conventional intervals to release the trees from neighboring competition. As such, the growth values included in our analyses may represent an underestimation of individual tree growth. However, predicted volumes at age 30 were within the range of volume observed in other sites that were thinned and had a final tree planting density between 330 and 400 trees per hectare (Piotto et al. 2010). 
Table 4 Mean net present value (US\$ ha ${ }^{-1}$ ) of treatments with changing interest rate for Scenario 2

\begin{tabular}{llllllll}
\hline Interest & \multicolumn{2}{l}{ Net present value $\left(\mathrm{US}^{2} \mathrm{ha}^{-1}\right.$ ) } & Pq mono & Pq-Ta mix & Ta mono & Tg mono \\
\cline { 2 - 5 } Rate $(\%)$ & Dr mono & Dr-Pq mix & Dr-Ta mix & & & & \\
\hline 1 & 97,648 & 30,440 & 12,267 & -251 & 6003 & 20,243 & 1879 \\
2 & 71,651 & 21,641 & 8118 & -1196 & 3457 & 14,053 & 465 \\
3 & 52,483 & 15,162 & 5071 & -1880 & 1593 & 9500 & -564 \\
4 & 38,311 & 10,381 & 2829 & -2373 & 226 & 6144 & -1312 \\
5 & 27,805 & 6845 & 1178 & -2726 & -776 & 3665 & -1855 \\
6 & 19,998 & 4226 & -39 & -2977 & -1509 & 1833 & -2247 \\
7 & 14,182 & 2282 & -936 & -3152 & -2045 & 477 & -2528 \\
8 & 9841 & 838 & -1596 & -3272 & -2435 & -527 & -2727 \\
9 & 6593 & -234 & -2080 & -3352 & -2717 & -1270 & -2866 \\
10 & 4160 & -1031 & -2435 & -3402 & -2919 & -1819 & -2961 \\
11 & 2334 & -1623 & -2693 & -3430 & -3061 & -2223 & -3022 \\
12 & 963 & -2061 & -2878 & -3441 & -3160 & -2519 & -3059 \\
13 & -68 & -2384 & -3010 & -3441 & -3226 & -2735 & -3078 \\
14 & -843 & -2621 & -3101 & -3433 & -3267 & -2890 & -3084 \\
15 & -1425 & -2793 & -3163 & -3418 & -3290 & -3001 & -3081 \\
\hline
\end{tabular}

Treatments include: Dr mono (D. retusa monoculture), Dr-Pq mix (D. retusa and $P$. quinata mixtures), Dr-Ta mix (D. retusa and T. amazonia mixtures), Pq mono (P. quinata monoculture), Pq-Ta mix ( $P$. quinata and T. amazonia mixture), Ta mono (T. amazonia monoculture) and Tg mono (Tectona grandis monoculture). italic represents where NPV changes from positive to negative

Although the volumes presented here will generally be lower than other studies because our volume estimates are merchantable volume (not volumes of the entire tree), there are many other factors that may explain why the volumes are low; from differences in management techniques to small differences in site characteristics that can lead to large differences in volume over time (Mayoral et al. 2019).

Although our results are disappointing from a $T$. grandis production perspective, we found alternative (native) species that have 2-4 times the volume growth after 30 years (Fig. 2). T. amazonia was the most productive tree of all those studied. Even the predicted absolute lowest limit $\left(\sim 100 \mathrm{~m}^{3} \mathrm{ha}^{-1}\right)$ would double the predicted absolute highest limit of T. grandis $\left(\sim 50 \mathrm{~m}^{3} \mathrm{ha}^{-1}\right)$ at year 30 . Further, Central Panama is not the only area where $T$. amazonia grows well. It has been shown to do reasonably well throughout Panama (van Breugel et al. 2011) and in parts of Costa Rica (Nichols 1994; Carpenter et al. 2004; Montagnini and Nair 2004). In fact, Montagnini and Nair (2004) found that T. amazonia stands in Costa Rica can reach $400 \mathrm{~m}^{3} \mathrm{ha}^{-1}$ after only 12 years (albeit these volumes are total tree volumes), compared to an estimated $>125 \mathrm{~m}^{3} \mathrm{ha}^{-1}$ in the stands studied here (Fig. 2a). While low soil fertility and steep slopes, characteristic of our study site, can negatively affect the growth of T. amazonia (Mayoral et al. 2019), this underscores the importance of matching species to site, and the importance of trials to test how species will perform on a particular site.

Similar to T. amazonia, D. retusa was projected to grow well in the study site (Fig. 2d), while $P$. quinata was planted with the expectation that it would grow, but not very well (van Breugel et al. 2011; Hall and Ashton 2016). Though the predicted volume at 30 years of $P$. quinata and D. retusa was less than half of that of $T$. amazonia, volume of both species is predicted to exceed that of $T$. grandis. Over the first 10 years, neither D. retusa nor 
$P$. quinata did particularly well when planted with $T$. amazonia due to the dominant nature of $T$. amazonia. In contrast, when $D$. retusa and $P$. quinata were planted together, $P$. quinata was significantly more productive than the monocultures of either species. Indeed, Mayoral et al. (2017) found $P$. quinata to transgressively overyield with $D$. retusa at this site. The contrasting performance of the three species in mixtures stresses the importance of light competition in plantations. While these species can grow in partial shade (Marshall et al. 2020), productivity can be hampered when light becomes too limiting, as it does in the case of $D$. retusa and $P$. quinata planted with $T$. amazonia (Sinacore et al. 2020). This highlights that, if the goal is for both species in a mixture to accumulate volume (or biomass), selecting complementary species is important (Forrester et al. 2006; Ewel and Mazzarino 2008).

The purpose of the study was not only to model and evaluate the volume of different species in monocultures and mixtures over time, but to also evaluate the financial viability of different species and compare them to $T$. grandis. Although predicted volume of D. retusa is lower than the other three species, its predicted net present value (NPV) far exceeded that of the other species. The absolute maximum (and most optimistic case in scenario 2) predicts that $D$. retusa monocultures could have an NPV of US $\$ 210,000 \mathrm{ha}^{-1}$ at a discount rate of $1 \%$. Even if the discount rate is $6 \%$, in the most optimistic growth projection (in scenario 2), D. retusa monocultures were predicted to have an NPV of nearly $\sim$ US $\$ 100,000 \mathrm{ha}^{-1}$ (Fig. 3a). What is even more notable about D. retusa is that NPV only drops below zero when the interest rate is $>13 \%$ (based on an average scenario 2), suggesting an internal rate of return between 12 and 13\%. This starkly contrasts $P$. quinata monocultures which did not have a positive NPV in this scenario or T. grandis monocultures which had a negative NPV at discount rates $\geq 3 \%$ (Fig. 3d,g; Table 4). Generally, the interest rates of $T$. grandis plantations in Central and South American range from 5 to $13 \%$ (Griess and Knoke 2011; Stefanski et al. 2015). Based on our results, it is unrealistic and risky to plant $P$. quinata or T. grandis monocultures or mixtures of P. quinata and T. amazonia because NPV already falls below zero at low discount rates, except for in the most optimistic scenarios (Fig. 3 and see Table S1).

While $D$. retusa clearly outcompetes any other species in this study financially and is the least risky option from a financial perspective, this study does not attempt to evaluate the many unknowns associated with plantation forestry, including a potentially positive (though likely modest) effect of nutrient addition. For any selected species, there is always the risk that drought might negatively impact a species that is particularly vulnerable to drought (Gavinet et al. 2019) or that the species is susceptible to pest damage (Paul et al. 2012). Yet recent tree physiology studies at our site found D. retusa well equiped to respond to one of the worst droughts recorded in 100 years in Central Panama (Sinacore et al. 2019; 2020). Further, demand for certain wood can positively or negatively affect the value of the logs, which is hard to predict in advance of the trees reaching harvest age. Finally, social and political climates can affect domestic and international trade of certain species (Vardeman and Runk 2020), neither of which we attempt to quantify in this article.

\section{Conclusions}

Plantations have and will continue to serve diverse productive, economic, and ecological functions (Montagnini and Porras 1998). Tropical plantations, in particular, have relatively high yields and can provide a significant portion of wood to domestic and international 
markets. Yet growth and productivity of $T$. grandis are known to be poor in areas of low soil fertility (Keogh 1982; Lugo 1997). This is particularly important in Panama, where opportunities for plantations are often relegated to marginal lands where soils do not support productive $T$. grandis. Our work shows that T. amazonia and D. retusa are safe alternatives that have been proven successful on low fertility soils (Mayoral et al. 2019). A major obstacle is often the lack of knowledge in planting and caring for specific species, but recent advances have reduced this barrier (Hall and Ashton 2016). This paper helps to fill an important gap — projecting growth and financial returns when planting different species at a nutrient poor site. Two of the species herein (T. amazonia and D. retusa) grow well, while $T$. grandis and $P$. quinata grow poorly, and there are clear differences in net present values. There is a conspicuous economic advantage to planting $D$. retusa over T. amazonia, but $T$. amazonia also shows promise, either as a monoculture or in mixture with $D$. retusa. However, T. amazonia may also have advantageous growth with other species, especially those that have poor growth when combined with $T$. amazonia. Despite this information, changing landowners' perceptions and transitioning from one species to a lesser known one, is a risk for the landowner and may require financial incentives (Fenichel et al. 2019).

Supplementary Information The online version contains supplementary material available at https://doi. org/10.1007/s11056-022-09906-0.

Acknowledgements This work was made possible by the Agua Salud Project and the Smart Reforestation ${ }^{\circledR}$ program of the Smithsonian Tropical Research Institute (STRI). Agua Salud is part of ForestGEO and is a collaboration between STRI, the Panama Canal Authority and the Ministry of the Environment in Panama. The Agua Salud plantations also participate in the TreeDiVNet network. Funding for this study was provided by Lloyd's Tercentenary Research Foundation and the Working Land and Seascapes Program of the Smithsonian Institution's Conservation Commons, and the Mark and Rachel Rohr Foundation. Core Agua Salud support comes from Frank and Kristin Levinson, Stanley Motta, the Hoch Family. We would like to thank Mario Bailon, Anabel Rivas, Johana Balbuena, Miguel Nunez, Guillermo Fernandez, Julia Gonzalez, and many interns and technicians for their work measuring the plantations and managing the data.

Author contributions KS, JSH, and MvB designed the study. KS and EHG collected the data. KS and TH carried out the data analysis with input from JSH, MvB, AJF and OL. KS and JSH wrote the manuscript and it was reviewed and edited by all other coauthors.

Funding The first author was supported by grants and fellowships from the Smart Reforestation ${ }^{\circledR}$ program of the Smithsonian Tropical Research Institute, Mr. Stanley Motta, Frank and Kristin Levinson, the HeisingSimons Foundation, the University of New Hampshire, Lloyds Tercentenary Research Foundation, the Mark and Rachel Rohr Foundation, and the Working Land and Seascapes Program of the Smithsonian Institution's Conservation Commons. The second author is supported by the Smithsonian Tropical Research Institute, Dr. Ross Robertson, the University of Panama, and the Secretaría Nacional de Ciencia, Tecnología e Innovación.

Data availability The data will be available upon reasonable request. Please contact JSH.

Code availability The code will be available upon reasonable request via contact with KS.

\section{Declarations}

Conflict of interest The authors declare there are no conflicts of interest.

Open Access This article is licensed under a Creative Commons Attribution 4.0 International License, which permits use, sharing, adaptation, distribution and reproduction in any medium or format, as long as you give appropriate credit to the original author(s) and the source, provide a link to the Creative Commons licence, and indicate if changes were made. The images or other third party material in this article 
are included in the article's Creative Commons licence, unless indicated otherwise in a credit line to the material. If material is not included in the article's Creative Commons licence and your intended use is not permitted by statutory regulation or exceeds the permitted use, you will need to obtain permission directly from the copyright holder. To view a copy of this licence, visit http://creativecommons.org/licenses/by/4.0/.

\section{References}

Ashton MS (1995) Seedling growth of co-occurring Shorea species in the simulated light environments of a rain forest. For Ecol Manage 72:1-12

Ashton MS, Gunatilleke CVS, Singhakumara BMP, Gunatilleke IAU (2001) Restoration pathways for rain forest in southwest Sri Lanka: a review of concepts and models. For Ecol Manage 154:409-430. https://doi.org/10.1016/S0378-1127(01)00512-6

Augspurger CK, Augspurger CK (1984) Light requirements of neotropical tree seedlings: a comparative study of growth and survival. J Ecol 72:777-795

Avery TE, Burkhart HE (2015) Forest measurements. Waveland Press, Long Grove

Bastin JF, Finegold Y, Garcia C et al (2019a) The global tree restoration potential. Science 364:76-79. https://doi.org/10.1126/science.aax0848

Bastin JF, Finegold Y, Garcia C et al (2019b) Response to Comment on "The global tree restoration potential." Science 366:1-7. https://doi.org/10.1126/science.aaz0493

Bermejo I, Cañellas I, San Miguel A (2004) Growth and yield models for teak plantations in Costa Rica. For Ecol Manage 189:97-110. https://doi.org/10.1016/j.foreco.2003.07.031

Bhangu PKS (2018) Economic Evaluation of Poplar based Agro-forestry System in Punjab. Econ Aff 63:679-685. https://doi.org/10.30954/0424-2513.3.2018.12

Butterfield RP (1995) Promoting biodiversity: advances in evaluating native species for reforestation. For Ecol Manage 75:111-121

Carpenter FL, Nichols JD, Sandi E (2004) Early growth of native and exotic trees planted on degraded tropical pasture. For Ecol Manage 196:367-378. https://doi.org/10.1016/j.foreco.2004.03.030

Didier ATJ, Rodrigue I, Achille A et al (2016) History, Impact of Soil Types on Stand Structure and Growth of the Dry Zone Mahogany (Khaya senegalensis (Desr.) A.Juss.) in Plantation in Benin (West Africa). Environ Ecol Res 4:193-199. https://doi.org/10.13189/eer.2016.040402

dos Reis SM, Talamini E, da Silva Neto PJ et al (2019) Growth and yield of mahogany wood in cocoa-based agroforestry systems of two soil types in the Brazilian Amazon. Agrofor Syst 93:2163-2172. https:// doi.org/10.1007/s10457-018-0327-2

Ewel JJ, Celis G, Schreeg L (2015) Steeply increasing growth differential between mixture and monocultures of tropical trees. Biotropica 47:162-171. https://doi.org/10.1111/btp.12190

Ewel JJ, Mazzarino MJ (2008) Competition from below for light and nutrients shifts productivity among tropical species. Proc Natl Acad Sci USA 105:18836-18841. https://doi.org/10.1073/pnas.0807216105

FAO (2015) Forest Resources Assessment: Evaluación de los recursos forestales mundiales 2015 de Panama

Fenichel EP, Adamowicz W, Ashton MS, Hall JS (2019) Incentive systems for forest-based ecosystem services with missing financial service markets. J Assoc Environ Resour Econ 6:319-347. https://doi.org/ $10.1086 / 701698$

Forrester DI, Bauhus J, Cowie AL, Vanclay JK (2006) Mixed-species plantations of Eucalyptus with nitrogen-fixing trees: a review. For Ecol Manage 233:211-230. https://doi.org/10.1016/j.foreco.2006.05. 012

Forrester DI, Smith RGB (2012) Faster growth of Eucalyptus grandis and Eucalyptus pilularis in mixedspecies stands than monocultures. For Ecol Manage 286:81-86. https://doi.org/10.1016/j.foreco.2012. 08.037

Freese F (1973) A collection of log rules. USDA Forest Service General Technical Report. Forest Products Laboratory

Friday KS (1987) Site index curves for teak ( $<\mathrm{i}>$ Tectona grandis L. $<\mathrm{i}>$ ) in the limestonen hill region of Puerto Rico. Commonw for Rev 66:239-253

Gavinet J, Ourcival J, Limousin J (2019) Rainfall exclusion and thinning can alter the relationships between forest functioning and drought. New Phytol. https://doi.org/10.1111/nph.15860

Griess VC, Knoke T (2011) Can native tree species plantations in Panama compete with Teak plantations? An economic estimation. New for 41:13-39

Griscom BW, Adams J, Ellis PW et al (2017) Natural climate solutions. Proc Natl Acad Sci USA 114:11645-11650. https://doi.org/10.1073/pnas.1710465114 
Griscom HP, Ashton PMS, Berlyn GP (2005) Seedling survival and growth of native tree species in pastures: Implications for dry tropical forest rehabilitation in central Panama. For Ecol Manage 218:306318. https://doi.org/10.1016/j.foreco.2005.08.026

Hall JS (2013) Growth and Development of the Agua Salud Teak (Tectona grandis) Plantation Four Growing Seasons Post-Establishment

Hall JS, Ashton PMS (2016) guide to early growth and survival in plantations of 64 tree species native to Panama and the neotropics. Smithsonian Tropical Research Institute, Balboa

Hall JS, Love BE, Garen EJ et al (2011) Tree plantations on farms: Evaluating growth and potential for success. For Ecol Manage 261:1675-1683. https://doi.org/10.1016/j.foreco.2010.09.042

Hall JS, Kirn V, Yanguas-Fernandez E (Eds.) (2015) Managing watersheds for ecosystem services in the steepland neotropics. Inter-American development bank monograph, 340. 186 pp. https://stri.si.edu/ scientist/jefferson-hall/publications

Hall JS, Plisinksi JS, Mladinich SK, van Breugel M, Lai HR, Asner GP, Walker K, Thompson JR (2022) Deforestation scenarios show the importance of secondary forest for meeting Panama's carbon goals. Landsc Ecol. https://doi.org/10.1007/s10980-021-01379-4

Hassler SK, Zimmermann B, van Breugel M et al (2011) Recovery of saturated hydraulic conductivity under secondary succession on former pasture in the humid tropics. For Ecol Manage 261:1634-1642. https://doi.org/10.1016/j.foreco.2010.06.031

Healy C, Gotelli NJ, Potvin C (2008) Partitioning the effects of biodiversity and environmental heterogeneity for productivty and mortality in a tropical tree plantation. J Ecol 96:903-913

Holl KD, Brancalion PHS (2020) Tree planting is not a simple solution. Science 368:580-581. https://doi. org/10.1126/science.aba8232

Howard AF, Valerio J (1996) Financial returns from sustainable forest management and selected agricultural land-use options in Costa Rica. For Ecol Manage 81:35-49. https://doi.org/10.1016/0378-1127(95) 03670-9

Hutchison C, Gravel D, Guichard F, Potvin C (2018) Effect of diversity on growth, mortality, and loss of resilience to extreme climate events in a tropical planted forest experiment. Sci Rep 8:1-10. https://doi. org/10.1038/s41598-018-33670-x

Kelty MJ (1992) Comparative productivity of monocultures and mixed-species stands. Ecol Silvic Mix for. https://doi.org/10.1007/978-94-015-8052-6

Keogh RM (1982) Teak ( $<\mathrm{i}>$ Tectona grandis $<\mathrm{i}>$ Linn. f.) provisional site classification chart for the Caribbean, Central America Venezuela and Colombia. For Ecol Manage 4:143-153

Kirby KR, Potvin C (2017) Variation in carbon storage among tree species: implications for the management of small-scale carbon sink project. For Ecol Manage 246:208-221

Kollert W, Chrubini L (2012) Teak Resources and Market Assessment 2010. FAO Plant For Trees Work Pap F.P. $47 \mathrm{E}$

Kraenzel M, Castillo A, Moore T, Potvin C (2003) Carbon storage of harvest-age teak (Tectona grandis) plantations, Panama. For Ecol Manage 173:213-225. https://doi.org/10.1016/S0378-1127(02)00002-6

Lewis SL, Wheeler CE, Mitchard ETA, Koch A (2019) Restoring natural forests is the best way to remove atmospheric carbon. Nature 568:25-28. https://doi.org/10.1038/d41586-019-01026-8

Lugo AE (1997) The appartment paradox of resstablishing species richness on degraded lands with tree monocultures. For Ecol Manage 99:9-19

Marshall A, McLaughlin BP, Zerr C et al (2020) Early indications of success rehabilitating an underperforming teak (Tectona grandis) plantation in Panama through enrichment planting. New for. https:// doi.org/10.1007/s11056-020-09801-6

Martin-Benito D, Pederson N, Köse N et al (2018) Pervasive effects of drought on tree growth across a wide climatic gradient in the temperate forests of the Caucasus. Glob Ecol Biogeogr 27:1314-1325. https:// doi.org/10.1111/geb.12799

Mayoral C, van Breugel M, Cerezo A, Hall JS (2017) Survival and growth of five Neotropical timber species in monocultures and mixtures. For Ecol Manage 403:1-11. https://doi.org/10.1016/j.foreco.2017. 08.002

Mayoral C, van Breugel M, Turner BL et al (2019) Effect of microsite quality and species composition on tree growth: a semi-empirical modeling approach. For Ecol Manage 432:534-545. https://doi.org/10. 1016/j.foreco.2018.09.047

Medeiros G, Florindo T, Talamini E et al (2020) Optimising tree plantation land use in brazil by analysing trade-offs between economic and environmental factors using multi-objective programming. Forests 11:723. https://doi.org/10.3390/f11070723

Montagnini F, González E, Porras C et al (1995) Mixed and pure forest plantations in the humid neotropics: a comparison of early growth, pest damage and establishment costs. Commonw Assoc 74:306-314. https://doi.org/10.2307/42608324 
Montagnini F, Nair PKR (2004) Carbon sequestration: an underexploited environmental benefit of agroforestry systems. Agrofor Syst 61:281-295

Montagnini F, Porras C (1998) Evaluating the role of plantations as carbon sinks: an example of an integrative approach from the humid tropics. Environ Manage 22:459-470. https://doi.org/10.1007/ s002679900119

Navarro CM, Martinez H. (1988) El pochote (Bombacopsis quinatum) en Costa Rica: guía silvicultural para el establecimiento en plantaciones. CATIE, Turrialba (Costa Rica). Proyecto de Arboles de Uso Múltiple

Nichols D (1994) Terminalia amazonia (Gmel.) Exell: development of a native species for reforestation and agroforestry. Commonw Rev 73:9-13

Ogden FL, Crouch TD, Stallard RF, Hall JS (2013) Effect of land cover and use on dry season river runoff, runoff efficiency, and peak storm runoff in the seasonal tropics of Central Panama. Water Resour Res 49:8443-8462. https://doi.org/10.1002/2013WR013956

Pandey SBS, Jadeja DB, Manohar NS, Tandel MB (2016) Economic comparison of intercropping of ginger and turmeric under sapota-jatropha based agro-forestry systems in south Gujarat. Int J Sci Environ Technol 5:3635-3642

Paul C, Griess VC, Havardi-Burger N, Weber M (2015) Timber-based agrisilviculture improves financial viability of hardwood plantations: a case study from Panama. Agrofor Syst 89:217-235. https://doi. org/10.1007/s 10457-014-9755-9

Paul GS, Montagnini F, Berlyn GP et al (2012) Foliar herbivory and leaf traits of five native tree species in a young plantation of Central Panama. New for 43:69-87. https://doi.org/10.1007/ s11056-011-9267-7

Piotto D, Craven D, Montagnini F, Alice F (2010) Silvicultural and economic aspects of pure and mixed native tree species plantations on degraded pasturelands in humid costa rica. New for 39:369-385. https://doi.org/10.1007/s11056-009-9177-0

Plath M, Mody K, Potvin C, Dorn S (2011) Establishment of native tropical timber trees in monoculture and mixed-species plantations: small-scale effects on tree performance and insect herbivory. For Ecol Manage 261:741-750

Potvin C, Mancilla L, Buchmann N et al (2011) An ecosystem approach to biodiversity effects: Carbon pools in a tropical tree plantation. For Ecol Manage 261:1614-1624

R Core Team (2017) A language and environment for statistical computing

Rode R, Leite HG, da Silva ML et al (2014) The economics and optimal management regimes of eucalyptus plantations: a case study of forestry outgrower schemes in Brazil. For Policy Econ 44:26-33. https://doi.org/10.1016/j.forpol.2014.05.001

Salles TT, Nogueira DA, Beijo LA, da Silva LF (2019) Bayesian approach and extreme value theory in economic analysis of forestry projects. For Policy Econ 105:64-71

Schnabel F, Schwarz JA, Dănescu A et al (2019) Drivers of productivity and its temporal stability in a tropical tree diversity experiment. Glob Chang Biol. https://doi.org/10.1111/gcb.14792

Sinacore K, Asbjornsen H, Hernandez-santana V, Hall JS (2019) Drought differentially affects growth, transpiration, and water use efficiency of mixed and monospecific planted forests. Forests 10:1-19. https://doi.org/10.3390/f10020153

Sinacore K, Asbjornsen H, Hernandez-Santana V, Hall JS (2020) Differential and dynamic water regulation responses to El Niño for monospecific and mixed species planted forests. Ecohydrology. https://doi.org/10.1002/eco.2238

Singhakumara BMP, Gamage HK, Ashton MS (2003) Comparative growth of four Syzygium species within simulated shade environments of a Sri Lankan rain forest. For Ecol Manage 174:511-520

Sloan S (2007) Reforestation amidst deforestation in the Bayano-Darién frontier, Eastern Panama: Variations on the forest transition thesis

Smith DM, Larson BC, Kelty MJ, Ashton PMS (1997) The practice of silviculture: applied forest ecology. Wiley, New York

Stan Development Team (2020) RStan: the R interface to Stan

Stallard RF, Ogden F, Elsenbeer H, Hall JS (2010) Canal watershed experiment: Agua Salud project. Water Resour Impact 12:17-20

Stefanski SF, Shi X, Hall JS et al (2015) Teak-cattle production tradeoffs for Panama Canal Watershed small scale producers. For Policy Econ 56:48-56. https://doi.org/10.1016/j.forpol.2015.04.001

Stille L, Smeets E, Wicke B et al (2011) The economic performance of four (agro-) forestry systems on alkaline soils in the state of Haryana in India. Energy Sustain Dev 15:388-397. https://doi.org/10. 1016/j.esd.2011.08.002

Tarbox BC, Fiestas C, Caughlin TT (2018) Divergent rates of change between tree cover types in a tropical pastoral region. Landsc Ecol 33:2153-2167. https://doi.org/10.1007/s10980-018-0730-0 
Torres DA, del Valle JI, Restrepo G (2012) Site index for teak in Colombia. J for Res 23:405-411. https:// doi.org/10.1007/s11676-012-0277-X

Upadhyay A, Eid T, Sankhayan PL (2005) Construction of site index equations for even aged stands of Tectona grandis (teak) from permanent plot data in India. For Ecol Manage 212:14-22. https://doi.org/10. 1016/j.foreco.2005.02.058

van Breugel M, Craven D, Lai HR et al (2019) Soil nutrients and dispersal limitation shape compositional variation in secondary tropical forests across multiple scales. J Ecol 107:566-581. https://doi.org/10. $1111 / 1365-2745.13126$

van Breugel M, Hall JS (2008) Experimental design of the "Agua Salud" Native Timber Species Plantation 2008

van Breugel M, Hall JS, Craven DJ et al (2011) Early growth and survival of 49 tropical tree species across sites differing in soil fertility and rainfall in Panama. For Ecol Manage 261:1580-1589. https://doi.org/ 10.1016/j.foreco.2010.08.019

Vardeman E, Runk JV (2020) Panama's illegal rosewood logging boom from Dalbergia retusa. Glob Ecol Conserv. https://doi.org/10.1016/j.gecco.2020.e01098

Wishnie M, Dent D, Mariscal E et al (2007) Initial performation and reforestation potential of 24 tropical tree species planted across precipitation gradient in the Republic of Panama. For Ecol Manag 243:39-49

Wright SJ, Samaniego MJ (2008) Historical, Demographic, and Economic Correlates of Land-Use Change in the Republic of Panama. Ecol Soc 13:155

Zonificación de Agropecuaria de Panamá (2006) Zonificación de suelos de Panamá por niveles de nutrientes. pp 1-24

Publisher's Note Springer Nature remains neutral with regard to jurisdictional claims in published maps and institutional affiliations. 